
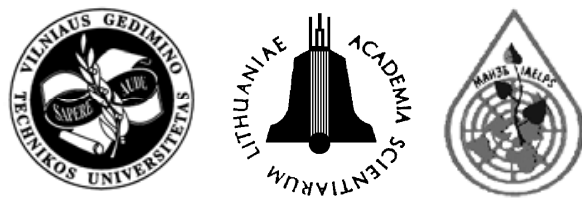

\title{
DETERMINATION OF OIL AND GREASE, TOTAL PETROLEUM HYDROCARBONS AND VOLATILE AROMATIC COMPOUNDS IN SOIL AND SEDIMENT SAMPLES
}

\author{
Teresa Rauckyte ${ }^{1}$, Slawomir $\dot{Z Z a k}^{2}$, Zenon Pawlak ${ }^{3}$, Adekunle Oloyede ${ }^{4}$ \\ ${ }^{1,2}$ Dept of Technology and Chemical Engineering, University of Technology and Life Sciences, \\ 85-326 Bydgoszcz, 3 Seminaryjna Street, Poland \\ ${ }^{3}$ Tribochemistry Consulting, Salt Lake City, Utah 84117, USA \\ and University of Economics, Biotribology Laboratory, 2 Garbary Street, 85-229 Bydgoszcz, Poland \\ ${ }^{4}$ Queensland University of Technology, School of Engineering Systems, GPO Box 2434, \\ Brisbane, Q 4001, Australia \\ E-mail: ${ }^{1}$ terra@utp.edu.pl (corresponding author) \\ Submitted 1 Jun. 2009; accepted 20 Oct. 2009
}

\begin{abstract}
This paper describes a case study of petroleum-contaminated soil/sediment samples which were analyzed using gas chromatography-flame ionization detector (GC-FID) for total petroleum hydrocarbons (TPH), volatile aromatic compounds: benzene, toluene, ethylbenzene, and xylenes (BTEX) and naphthalene by GC-MS, and oil and grease (O/G) content by sonication in hexane. The ratio of $(\mathrm{TPH}) /(\mathrm{O} / \mathrm{G})$ shows that the hydrocarbon fraction is between $7 \%$ and $87 \%$. The content of volatile organic fraction BTEX accounts for only a small proportion of total TPH, and the ratio of (BTEX) / (TPH) ranges from $0.1 \%$ to $0.6 \%$. It should be stressed that the use of TPH methods as against gas chromatography must be done with care because the potential risk posed by BTEX compounds may not be adequately addressed.
\end{abstract}

Keywords: soil/sediment, oil/grease, total petroleum hydrocarbons, volatile aromatic compounds.

\section{Introduction}

When petroleum products are released to the environment, physical, chemical, and biological processes change the contaminated site. Petroleum hydrocarbons released to the ground may move through the soil to the groundwater (Riccardi et al. 2008; Pawlak et al. 2008; Wang et al. 2002). Individual contaminant compounds at the site may separate from the original mixture, depending on the chemical properties of the compounds. Some of these compounds evaporate into the air (Laškova et al. 2007; Paulauskienè et al. 2009) and others will dissolve into groundwater and move away from the release area. Other compounds will attach to particles in the soil and may stay in the soil for a long time, while others will be broken down by the organisms found in the soil (Research Triangle Institute 1999).

Petroleum hydrocarbons (PHCs) are common site contaminants, but they are not generally regarded, and hence, regulated as hazardous wastes. PHCs indicate degradable and biodegradable properties in soil, water and sediment environment (Fedorak, Westlake 1981; Mills 1994; Prince et al. 1994; Leahy, Colwell 1990). The hydrocarbon analyses can be used for environmental assessment of remediation (Douglas et al. 1991) or soil bioremediation (Korda et al. 1997; Jørgensen et al. 2000). The term total petroleum hydrocarbons (TPH) is used to describe a broad family of several hundred chemical compounds that originally come from crude oil. It is useful to measure the total amount of all hydrocarbons found together in a particular sample of water, soil, or air. TPH is defined as the measurable amount of petroleum-based hydrocarbon in environmental media (Research Triangle Institute 1999; Gustafson 1997).

Re-refined petroleum products, e.g., gasoline, diesel fuel, used engine oil constitute a major class of contaminants for environmental investigators. Volatile aromatic hydrocarbons BTEX in unleaded gasoline contain benzene, toluene, ethylbenzene and xylenes in concentration above $10,000 \mathrm{ppm}$ for each compound in the ratio (1:5:1:5). In diesel fuel, BTEX compounds are present in concentration of about two orders of magnitude lower than gasoline in the ratio (1:3:2:14) for benzene, toluene, ethylbenzene and xylenes (Romeu 1990). The approximate carbon numbers for individual hydrocarbon products present in petroleum products are as follows: gasoline $\left(\mathrm{C}_{6}-\mathrm{C}_{12}\right)$, diesel $\left(\mathrm{C}_{8}-\right.$ $\left.\mathrm{C}_{26}\right)$, kerosene $\left(\mathrm{C}_{8}-\mathrm{C}_{18}\right)$, fuel oil $\left(\mathrm{C}_{17}-\mathrm{C}_{26}\right)$, and lubricating oils $\left(C_{21}-C_{50}\right)$ (George 1994).

Lubricating engine oil is a petroleum product that is a complex mixture of low and high molecular weight aliphatic and aromatic hydrocarbons $\left(\mathrm{C}_{21}-\mathrm{C}_{50}\right)$, metals, and additives. Additives (which can account for up to $20 \%$ of the weight of oil formulations) include detergents, metallic salts (e.g., molybdenum and zinc salts), and organometallic compounds. Metals (e.g., cadmium, lead and zinc) and polyaromatic hydrocarbons (PAHs) have been demonstrated to increase in oil with continued use in an engine (IARC 1984).

An oil and grease $(\mathrm{O} / \mathrm{G})$ contaminants are defined as any material recovered as a substance extracted in the form 
of organic solvent from a sample, and are composed primarily of fatty matter from animal and vegetable sources, hydrocarbons of petroleum origin, sulfur compounds, certain organic dyes, and chlorophyll. Many solvents are used in the determination of $\mathrm{O} / \mathrm{G}$ : petroleum ether, trichlorotrifluoroethane, a mixture $80 \%$ n-hexane $+20 \%$ methyltert-butyl ether, and currently n-hexane (Standard methods 1995). Methods developed for monitoring O/G included EPA 413.1, 1664, 9071A, and Standard Method 5520E. If $\mathrm{O} / \mathrm{G}$ is present in excessive amount, it may interfere with aerobic and anaerobic biological processes, leading to a decrease in wastewater treatment efficiency. The knowledge of the present $\mathrm{O} / \mathrm{G}$ quantity is helpful in the proper design and operation of wastewater systems and also for identifying treatment difficulties.

The TPH value represents a mixture of compounds and can be obtained from one of several analytical methods, some of which have been used for decades and others developed more recently, namely, EPA 418.1, 8015B, 1664 and 8020B. EPA method 418.1 provides a "one number" value of TPH in an environmental medium; it does not provide information on the composition (e.g., individual constituents of the hydrocarbon mixture). The amount of TPH measured by this method depends on the ability of the solvent used to extract the hydrocarbons from the environmental medium and the absorption of infrared (IR) light by the hydrocarbons in the solvent extract. At this juncture, it should be noted that the EPA method 418.1 is not specific to hydrocarbons and does not always indicate petroleum contamination. Method 418.1 has been one of the most widely used methods for determining TPH in soil analysis. Freon-extractable material has also been reported as $\mathrm{O} / \mathrm{G}$. Polar components may be removed by treatment with silica gel, and material remaining, as determined by IR-spectrometry, is defined as TPH. Therefore, EPA method 1664, "n-Hexane Extractable Material (HEM) and Silica Gel Treated n-Hexane Extractable Material (SGTHEM) by Extraction and Gravimetry (Oil and Grease and Total Petroleum Hydrocarbons)", will replace the methods using Freon-113 (US EPA method 1664, 2002).

Another analytical method commonly used for TPH is gas chromatography-flame ionization detector (GC/FID), a modified EPA method 8015B. The underground storage tank programs started in the mid-1980s, and they are capable of addressing groundwater contamination problems precisely. This gas chromatography (GC) method, coupled with specific extraction techniques, can provide information on the product type relative to values from chromatogram with benchmarks. Hence, there is a growing trend in the use of GC techniques in the analysis of soils and sediments. One aspect of this is that "volatiles" and "semivolatiles" are determined separately. The volatile or the gasoline range organic (GRO) components are recovered using purge-and-trap or stripping techniques. The semivolatile range is determined by the analysis of an extract by GC/FID and is referred to as diesel range organic (DRO). The results are most frequently reported as single numbers for purgeable and extractable hydrocarbon (US EPA method 8015B, 1986). Analytical methods that can provide more detailed information on the components of petroleum than traditional/standard methods are developed (Wang, Fingas 1997; Mills et al. 1999; Mc Kenzie et al. 1983; Roques et al. 1994).

The focus of this study was to identify and characterize O/G, TPH and BTEX and naphthalene in soil/ sediment samples. It continues an earlier publication concerning the determination of heavy metals, volatile aromatic compounds in used engine oils and sludges (Rauckyte et al. 2006).

\section{Methods}

The starting materials were obtained from "naturally" contaminated sites in a petroleum refinery at 5-10 cm deep. Soil samples 1-4 were taken from the area of so called petrochemical complex, and samples 5-9 from the refinery complex. Sediments for samples 10-11 were taken from retention containers storing groundwater and rain water from the refinery complex and samples 12-13 from the same containers but storing water from the petrochemical complex. In case of samples 14 and 15, they were taken from water pumps containers: 14 from the refinery complex and 15 from the petrochemical complex. Samples from this refinery were prepared and analyzed in accordance with EPA procedures and methods: 9071A, 8015B, and 8020B.

The oil/grease EPA method 9071A is a procedure for extracting nonvolatile and semivolatile organic compounds from solids such as soil, sediments, sludges, and industrial and domestic wastes. The sonication process ensures the intimate contact of the matrix with n-hexane during the extraction. The method is not applicable to measure light hydrocarbons that volatilize at temperature below $70^{\circ} \mathrm{C}$ (US EPA method 9071A, 1994), with the method reported limit (MRL) of $50 \mathrm{ppm}$.

The TPH were measured by EPA method $8015 \mathrm{~B}$ gas chromatography/flame ionization detection (GC/FID) with reported method of limit $10 \mathrm{ppm}$ for soil/sediment (US EPA method 8015B).

The gas chromatography-mass spectrometry (GC/MS) method 8020B was used for analysis of benzene, toluene, ethylbenzene, xylenes, and naphthalene (BTEX) in soil/sediment samples. The reporting limit was $0.025 \mathrm{ppm}$ for benzene, toluene ethylbenzene, m-xylene and $0.050 \mathrm{ppm}$ for o- and p-xylene and naphthalene. The standards were prepared as specified in EPA method 8020B (US EPA method 8020B, 1992).

\section{Results and discussion}

The results of the oil/grease, total petroleum hydrocarbon and volatile organic compounds are presented in Table 1. The oil/grease in soil samples $(n=9)$ ranged from $100 \mathrm{ppm}$ to $2400 \mathrm{ppm}$, and in sediment samples $(\mathrm{n}=6)$ ranged from $3400 \mathrm{ppm}$ to $13800 \mathrm{ppm}$. A similar trend was observed for total petroleum hydrocarbon (TPH) levels which in soil samples $(n=9)$ ranged from 20 to $400 \mathrm{ppm}$, and in sediment samples $(\mathrm{n}=6)$ ranged from 850 to $1250 \mathrm{ppm}$. The mean ratio of $(\mathrm{TPH}) /(\mathrm{O} / \mathrm{G})$ in soil samples ranged from $7 \%$ to $87 \%$, and in sediment samples ranged from $8 \%$ to $27 \%$. 
Table 1. Oil/grease (O/G), total petroleum hydrocarbons (TPH) and volatile aromatic compounds (BTEX) in soil/sediment samples

\begin{tabular}{|c|c|c|c|c|c|}
\hline $\begin{array}{l}\text { Sample, } \\
\text { origin }\end{array}$ & $\begin{array}{c}\begin{array}{c}\mathrm{O} / \mathrm{G}^{\mathrm{a}} \\
(\mathrm{ppm})\end{array} \\
\mathrm{EPA} \\
9071 \mathrm{~A}\end{array}$ & $\begin{array}{c}\mathrm{TPH}^{\mathrm{a}} \\
(\mathrm{ppm}) \\
\text { EPA } \\
8015 \mathrm{~B}\end{array}$ & $\begin{array}{c}{[\mathrm{TPH}] /} \\
{[\mathrm{O} / \mathrm{G}]} \\
(\%)\end{array}$ & $\begin{array}{l}\text { Volatile organic compound (BTEX) }{ }^{\mathrm{a}} \\
(\mathrm{ppm}) \text {, EPA method 8020B }\end{array}$ & $\begin{array}{c}\text { [BTEX] / } \\
{[\mathrm{TPH}]} \\
(\%)\end{array}$ \\
\hline 1 soil & 2400 & 400 & 16.7 & Benzene (0.35), ethylbenzene (0.13), xylenes $(0.28)$ & 0.19 \\
\hline 2 soil & 280 & 90 & 33.2 & Benzene (0.03), ethylbenzene $(0.10)$, toluene $(0.03)$ & 0.18 \\
\hline 3 soil & 150 & 130 & 86.7 & Toluene (0.10), xylenes (0.06) & 0.12 \\
\hline 4 soil & 220 & 40 & 15.9 & Benzene (0.03), toluene (0.13), xylenes $(0.08)$ & 0.60 \\
\hline 5 soil & 170 & 65 & 41.2 & Toluene (0.08), xylenes $(0.06)$ & 0.17 \\
\hline 6 soil & 1000 & 140 & 14.0 & $\begin{array}{c}\text { Benzene (0.03), ethylbenzene (0.15), toluene (0.03), } \\
\text { xylenes }(0.05)\end{array}$ & 0.19 \\
\hline 7 soil & 100 & 80 & 80.0 & Benzene (0.03), toluene (0.03), xylenes $(0.24)$ & 0.38 \\
\hline 8 soil & 290 & 20 & 6.9 & Ethylbenzene (0.03), naphthalene (0.05), xylenes (0.03) & 0.16 \\
\hline 9 soil & 1700 & 340 & 20.0 & $\begin{array}{c}\text { Benzene (0.12), ethylbenzene }(0.10) \text {, toluene (0.08), } \\
\text { xylenes }(0.30)\end{array}$ & 0.22 \\
\hline 10 sedim & 11900 & 1250 & 10.5 & Benzene (0.50), naphthalene (0.10), xylenes (1.20) & 0.12 \\
\hline 11 sedim & 11400 & 1100 & 9.6 & $\begin{array}{c}\text { Benzene (0.51), ethylbenzene (0.25), toluene (0.22), } \\
\text { xylenes }(0.23)\end{array}$ & 0.11 \\
\hline 12 sedim & 13800 & 1160 & 8.4 & Benzene (0.30), ethylbenzene (0.23), xylenes $(0.77)$ & 0.11 \\
\hline 13 sedim & 7500 & 1050 & 14.0 & Benzene (0.53), ethylbenzene (0.35), xylenes $(0.38)$ & 0.12 \\
\hline 14 sedim & 3400 & 850 & 25.0 & Benzene (0.29), toluene (0.12), xylenes $(0.78)$ & 0.14 \\
\hline 15 sedim & 3400 & 900 & 26.5 & $\begin{array}{c}\text { Benzene (0.15), ethylbenzene (0.46), toluene }(0.17) \text {, } \\
\text { xylenes }(0.39)\end{array}$ & 0.13 \\
\hline
\end{tabular}

Quality control (QC) parameters: Reference standard material, SRM (85-115\% recovery), Continuing check standard, CSTD (80120\%), Lab spike blank, LSB (85-115\%), Lab spike blank duplicate, LSBD (85-115\%), Lab spike matrix, LSM (80-120\%), Lab spike matrix duplicate LSMD (80-120\%).

${ }^{a}$ Accuracy (\% recovery) and precision (relative \% difference) of O/G, TPH and BTEX analysis: Accuracy was determined as a ratio of $\operatorname{LSB}_{\text {(found) }}$ to $\mathrm{LSB}_{\text {(true) }}(85 \%$ to $115 \%)$, or as a ratio of $\operatorname{LSM}_{\text {(found) }}$ to $\operatorname{LSM}_{\text {(true) }}(80 \%$ to $120 \%)$; the precision was determined by calculating the difference between the results found for the LSB and LSBD, and then dividing the difference by the average of the two results (3\% to $8 \%)$.

A linear relation between TPH and total O/G was observed (Fig. 1). This can be expressed: TPH $=$ $0.153 x+37.7, R^{2}=0.897$ for soil samples $(n=9)$, and the relation: $\mathrm{TPH}=0.032 \mathrm{x}+781.0, \mathrm{R}^{2}=0.861$ for sediments samples $(n=6)$. The total petroleum hydrocarbons from soil samples were effectively five times more concentrated than for sediment samples. The BTEX results in Table 1 indicate that the volatile fraction of aromatic hydrocarbons accounted for only a small part of the total TPH for contaminated samples and the ratios of (BTEX)/(TPH) ranged from $0.1 \%$ to $0.6 \%$.

A good correlation between measured BTEX and TPH was obtained (Fig. 2). This yielded the relation: $\operatorname{BTEX}(\mathrm{ppm})=0.0011 \mathrm{TPH}(\mathrm{ppm})+0.129 ; \mathrm{R}^{2}=0.955$, $\mathrm{n}=15$. Based on this correlation, the background BTEX (TPH $=0 \mathrm{ppm}$ ) was further estimated to be $\sim 0.115 \mathrm{ppm}$ for this contaminated site. The most contaminated area by BTEX was $1.8 \mathrm{ppm}$ at the same site (TPH was $1300 \mathrm{ppm}$ ).

Until recently, routine TPH analyses in soil samples have been performed by means of IR spectrometry method 418.1 (Standard methods 1995; ISO.TR 11046,
1992). However, this method is no longer supported by international standardization since the ban of 1,1,2trichlorotrifluoroethane as an extraction agent, and was replaced by gas chromatography/flame ionization detection (GC/FID) after extraction with a halogen-free solvent (US EPA method 8015B, 1986; ISO/DIS 16703, 2001).

The results of TPH obtained from 155 participants laboratories in three proficiency-testing rounds were compared in soil by IR - spectrometry and gas chromatography (Becker et al. 2002). Participants were supplied with soil samples with different levels of mineral oil content. Two methods: 418.1 IR - spectrometry and 8015B GC/FID-gas chromatography were compared with soil samples for analyzing TPH.

The results obtained with both methods were compared using 1,1,2 - trichlorotrifluoroethane (with IR quantification) and n-hexane (with GC/FID quantification) as the extraction solvents. The agreed value of the means obtained with (GC/FID) were typically $10 \%$ to $20 \%$ (ranging between $0 \%$ and $25 \%$ ) higher than those found with IR-spectroscopy (Becker et al. 2002). 


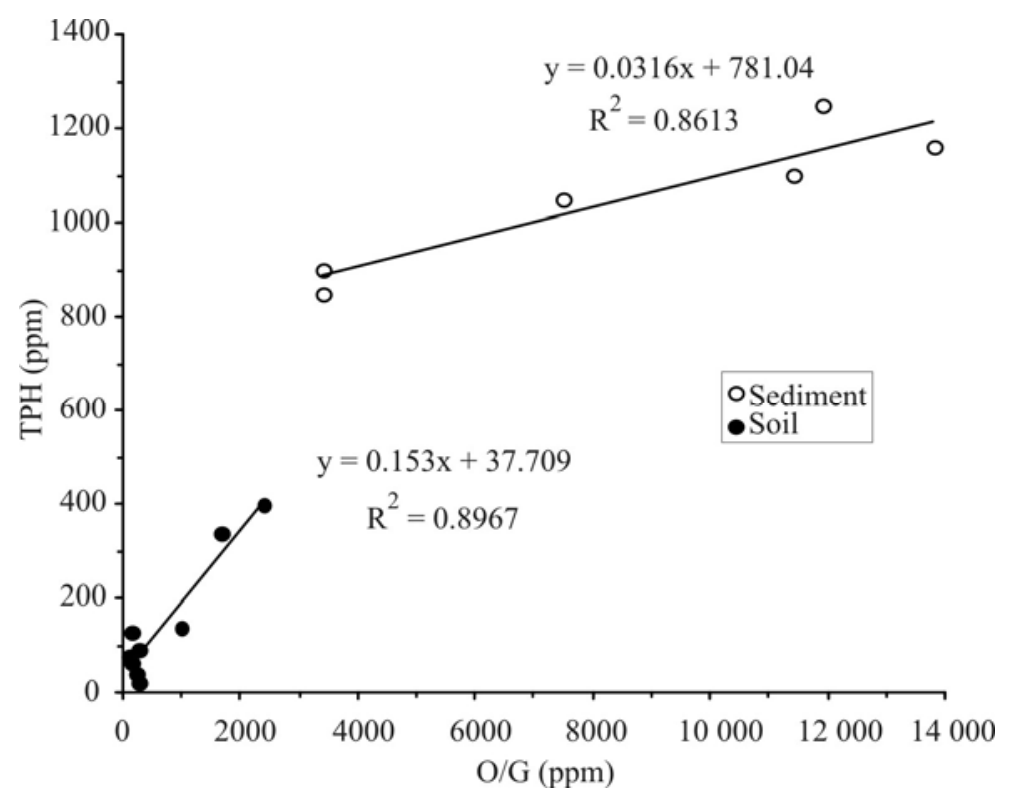

Fig. 1. Correlation between total petroleum hydrocarbon (TPH) and oil/grease $(\mathrm{O} / \mathrm{G})$ in soil and sediment samples

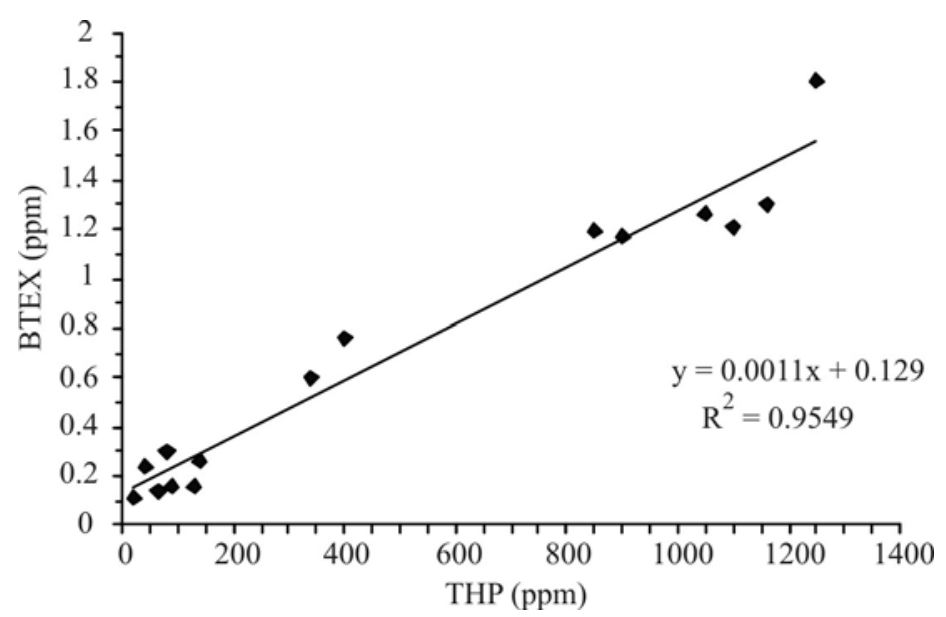

Fig. 2. Correlation between volatile aromatic fraction (BTEX) and total petroleum hydrocarbons $(\mathrm{TPH})$ in contaminated soil and sediment samples

Table 2. Minimal risk levels (MRL) and cancer classification for total petroleum hydrocarbon (TPH) components

\begin{tabular}{c|c|c|c}
\hline Chemical & MRL (inhalation) ${ }^{\mathrm{a}}, \mathrm{ppm}$ & MRL (oral) & EPA cancer classification $^{b}$ \\
\hline Gasoline & na & $\mathrm{na}^{\mathrm{c}}$ & na \\
\hline Diesel oil & $0.02 \mathrm{mg} / \mathrm{m}^{3}(\mathrm{AC})$ & na & na \\
\hline Engine oils & na & na & na \\
\hline Jet fuels & $9 \mathrm{mg} / \mathrm{m}^{3}(\mathrm{IN}, \mathrm{JP}-4 \mathrm{fuel})$ & na & group A \\
\hline Benzene & $0.05(\mathrm{AC}), 0.004(\mathrm{IN})$ & na & group D \\
\hline Ethylbenzene & $0.2(\mathrm{IN})$ & $0.05 \mathrm{mg} / \mathrm{kg} /$ day (AC) & group D \\
\hline Naphthalene & $0.002(\mathrm{CR})$ & na & group D \\
\hline Toluene & $0.02(\mathrm{AC}), 1(\mathrm{CR})$ & $0.8 \mathrm{mg} / \mathrm{kg} /$ day (AC) & group B2 $^{\mathrm{d}}, \mathrm{D}^{\mathrm{d}}$ \\
\hline Xylenes & $1(\mathrm{AC}), 0.7(\mathrm{CR}), 0.1(\mathrm{CR})$ & $1 \mathrm{mg} / \mathrm{kg} / \mathrm{day}(\mathrm{AC})$ & $0.6 \mathrm{mg} / \mathrm{kg} / \mathrm{day}(\mathrm{IN})$ \\
\hline PAHs & na & & \\
\hline
\end{tabular}

${ }^{a}$ Duration of exposure: acute (AC)-a duration of 14 days or less, intermediate (IN)-a duration of 15-365 days, and chronic (CR)-for 365 days or more.

${ }^{\mathrm{b}}$ EPA cancer classification (group): A = human carcinogen, B2 = probable human carcinogen, $\mathrm{C}=$ possible human carcinogen, $\mathrm{D}=$ not classifiable as to its carcinogenity to humans.

${ }^{\mathrm{c}}$ na $=$ data not available. 
${ }^{\mathrm{d}}$ group B2 = benzo(a)anthracene, benzo(b)fluoroanthene, chrystene, dibenz(a,h)-anthracene, indeno(1,2,3-c,-d)-pyrene; group $\mathrm{D}=$ acenaphthylene, anthracene, fluoranthene.

The obtained results are comparable with data obtained by other authors who made analyses of similar cases, for instance Taylor, Viraraghaven 1999 determined TPH in soil within the range from 2500 to $10000 \mathrm{ppm}$, and Paavo et al. 2008 in the extended range from 100 to 10000 ppm with the use of GC/FID technique. Data from Park's (San Juan 2000) paper remained at the same level. In literature, it is difficult to find data recording (TPH) / (O/G) and (BTEX) / (TPH) relations which were determined in our paper. So, the mentioned above relations in case of soils greatly depend on the intensity of biological transformations (Seo et al. 2009; Peng et al. 2008). However, the processes which are the causes of these phenomena can be used in practice for instance to eliminate VOC (Baltrènas, Zagorskis 2009; Del'Arco, De França 2001).

Despite the large number of hydrocarbons found in petroleum products, only a relatively small number of them were characterized for toxicity. The health effects of some fractions can be adequately characterized with respect to their components or representative compounds (e.g., light aromatic BTEX fraction (benzene, toluene, ethylbenzene, and xylenes) and naphthalene. The Agency for Toxic Substances and Disease Registry (ATSDR) does not assess cancer potency for TPH components, and toxicological information is only provided for some components, e.g., minimal risk level (MRL) (Research Triangle Institute 1999).

It is noteworthy that the health effects that are common to the BTEX compounds are of neurological nature (Mumtaz et al. 2004; Robinson, Mc Donell 2004; Pohl et al. 2003). Benzene has hematological effect and is classified in EPA Group A (human carcinogen). Minimal risk levels (MRL) and cancer classification for BTEX compounds and whole products are summarized in Table 2.

The inhalation minimal risk level for each of the BTEX compounds (acute MRL) was determined with the results indicating quantities of the components as: benzene $0.05 \mathrm{ppm}$, toluene $0.02 \mathrm{ppm}$, ethylbenzene $0.2 \mathrm{ppm}$, o-, m-, and p-xylene 1.0 ppm, and naphthalene 0.002 ppm (Research Triangle Institute 1999).

These mentioned above levels much exceeded the analyzed sediment samples (for example human carcinogen benzene $0.15-0.53 \mathrm{ppm}$, toluene $0.12-0.22 \mathrm{ppm}$ ) and they were lower in case of soil samples (benzene 0.12 and $0.35 \mathrm{ppm}$ for 9 and 1 soil respectively; toluene $0.03 \mathrm{ppm}$ (2, 6, 7 soil), 0.08 ppm (5, 9 soil) and 0.10 ppm (3 soil), 0.13 ppm (4 soil).

\section{Conclusions}

This paper describes a case study in which three analytical techniques including GC/MS, GC/FID, and sonication were used to identify and characterize oil/grease, total petroleum hydrocarbons and volatile aromatic compounds BTEX in soil and sediment samples. Our results and data interpretation clearly indicate that:

1. The contamination of soil/sediment samples by gasoline/diesel fuel is real and evident. The detected volatile aromatic hydrocarbons in soil and sediment samples were shown to have originated from gasoline/diesel fuels.

2. Samples of sediments were contaminated by TPH compounds, but to a much lesser degree (five times less) in comparison with soil sample.

3. The significant part of total petroleum hydrocarbons (TPH) was heavy petroleum product.

When a sediment is released onto the environment, PHCs cause serious damage to the water system, and their persistent toxic effect may last for over a long time. When treated appropriately by optimizing their biodegradation potential, hydrocarbons degrade occurs naturally, and with this, the main part of a PHCs-pollution can be eliminated more rapidly.

\section{References}

Baltrenas, P.; Zagorskis, A. 2009. Investigation of cleaning efficiency of a biofilter with an aeration chamber, Journal of Environmental Engineering and Landscape Management 17(1): 12-19. doi:10.3846/1648-6897.2009.17.12-19

Becker, R.; Koch, M.; Wachholz, S.; Win, T. 2002. Quantification of total petrol hydrocarbons (TPH) in soil by IRspectrometry and gas chromatography conclusions from three proficiency testing round, Accreditation and Quality Assurance 7(7): 286-289. doi:10.1007/s00769-002-0476-9

Del'Arco, J. P.; De França, F. P. 2001. Influence of oil contamination levels on hydrocarbon biodegradation in sandy sediment, Environmental Pollution 112(3): 515-519. doi:10.1016/S0269-7491(00)00128-7

Douglas, G. S.; McCarthy, K. J.; Dahlen, D. T.; Seavey, J. A.; Steinhauer, W. G.; Prince, R. C.; Elmendorf, D. L. 1991. The use of hydrocarbon analyses for environmental assessment and remediation, in Contaminated Soils: Diesel Fuel Contamination. Kostecki, P. T.; Calabrese, E. J. (Eds.). FL, Lewis Publishers, Boca Raton.

Fedorak, P. M.; Westlake, D. W. S. 1981. Degradation of aromatics and saturates in crude oil by soil enrichments, Water, Air, and Soil Pollution 16(3): 367-375. doi:10.1007/BF01046917

George, S. 1994. Bias associated with the use of EPA Method 418.1 for the determination of total petroleum hydrocarbons in soil, in Hydrocarbon Contaminated Soils. Calabrese, E. J.; Kostecki, P. T.; Bonazountas, M. (Eds.). Chelsea, Mich., Lewis Publishers, Vol. 4, chapter 8: 115142.

Gustafson, J. 1997. Using TPH in risk-based corrective action. Shell Development Corporation. Available from Internet: <http://www.epa.gov/swerust1/rbdm/tphrbca.htm>.

IARC 1984. Mineral oils. IARC monographs on the evaluation of the cancerogenic risk of chemicals to humans, International Agency for Research Cancer 33: 87-168.

ISO/DIS 16703. 2001. Soil quality-Determination of mineral oil content by gas chromatography.

ISO.TR 11046.1992. Soil quality-Determination of mineral oil content-Method: Infra-Red screening.

Jørgensen, K. S.; Puustinen, J.; Suortti, A.-M. 2000. Bioremediation of petroleum hydrocarbon-contaminated soil by composting in biopiles, Environmental Pollution 
107(2): 245-254. doi:10.1016/S0269-7491(99)00144-X

Korda, A.; Santas, P.; Tenente, A.; Santas, R. 1997. Petroleum hydrocarbon bioremediation: sampling and analytical techniques, in situ treatments and commercial microorganisms currently used, Applied Microbiology and Biotechnology 48(6): 677-686. doi:10.1007/s002530051115

Laškova, T.; Zabukas, V.; Vaitiekūnas, P. 2007. Influence of meteorological conditions on volatile organic compound spread in the atmospheric boundary layer, Journal of Environmental Engineering and Landscape Management 15(3): 135-143.

Leahy, J. G.; Colwell, R. R. 1990. Microbial degradation of hydrocarbons in the environment, Microbiological Reviews 54(3): 305-315.

Mc Kenzie, A. S.; Disko, U.; Rullkötter, J. 1983. Determination of hydrocarbon distribution in oils and sediment extracts by gas-chromatography - high resolution mass spectrometry, Organic Geochemistry 5(1): 57-63. doi:10.1016/0146-6380(83)90003-7

Mills, M. A. 1994. Biodegradation of petroleum hydrocarbons in aqueous and sediment environments. Masters Thesis. Texas A \& M University, College Station, TX.

Mills, M. A.; Mc Donald, T. J.; Bonner, J. S.; Simon, M. A.; Autenrieth, R. L. 1999. Method for quantifying the fate of petroleum in the environment, Chemosphere 39(14): 2563-2582. doi:10.1016/S0045-6535(99)00163-0

Mumtaz, M. M.; De Rosa, C. T.; Cibulas, W.; Falk, H. 2004. Seeking solutions to chemical mixtures challenges in public health, Environmental Toxicology and Pharmacology 18(1): 55-63. Research in Chemical Mixtures, ICCM2002 Symposium.

Park, H. S.; San Juan, C. 2000. A method for assessing leaching potential for petroleum hydrocarbons release sites: multiphase and multisubstance equilibrium partitioning, Soil and Sediment Contamination 9(6): 611-632. doi:10.1080/10588330091134437

Paulauskienė, T.; Zabukas, V.; Vaitiekūnas, P. 2009. Investigation of volatile organic compound (VOC) emission in oil terminal storage tank parks, Journal of Environmental Engineering and Landscape Management 17(2): 81-89. doi:10.3846/1648-6897.2009.17.81-88

Pawlak, Z.; Rauckyte, T.; Oloyede, A. 2008. Oil, grease and used petroleum oil management and environmental economic issues, Journal of Achievements in Materials and Manufacturing Engineering 26(1): 11-17.

Peng, R. H.; Xiong, A. S.; Xue, Y.; Fu, X. Y.; Gao, F.; Zhao, W.; Tian, Y. S.; Yao, Q. H. 2008. Microbial biodegradation of polyaromatic hydrocarbons, FEMS Microbiology Reviews 32(6): 927-955. doi:10.1111/j.1574-6976.2008.00127.x

Pohl, H. R.; Roney, N.; Wilbur, S.; Hansen, H.; De Rosa, C. T. 2003. Six interaction profiles for simple mixtures, Chemosphere 53(2): 183-197. doi:10.1016/S0045-6535(03)00436-3

Prince, R. C.; Elmendorf, D. L.; Lute, J. R.; Hsu, C. S.; Haith, C. E.; Senius, J. D.; Dechert, G. J.; Douglas, G. S.; Butler, E. L. 1994. 17*, $21 \beta(\mathrm{H})$-Hopane as a conserved internal marker for estimating the biodegradation of crude oil, Environmental Sciences and Technology 28(1): 142145. doi:10.1021/es00050a019

Rauckyte, T.; Hargreaves, D. J.; Pawlak, Z. 2006. Determination of heavy metals and volatile aromatic compounds in used engine oils and sludges, Fuel 85(4): 481-485. doi:10.1016/j.fuel.2005.08.004

Research Triangle Institute. 1999. Toxicological profile for total petroleum hydrocarbons (TPH). Prepared for U.S. Department of Health and Human Services.

Riccardi, C.; Di Filippo, P.; Pomata, D.; Incoronato, F.; Di Basilio, M.; Papini, M. P.; Spicaglia, S. 2008. Characterization and distribution of petroleum hydrocarbons and heavy metals in groundwater from three Italian tank farms, Science of the Total Environment 393(1): 50-63. doi:10.1016/j.scitotenv.2007.12.010

Robinson, P.; Mac Donell, M. 2004. Priorities for mixtures health effects research, Environmental Toxicology and Pharmacology 18(1): 201-213. Risk Assessment of Chemical Mixtures, ICCM- 2002 Symposium.

Romeu, A. A.; King, C.; Blevins, D. J.; Soutor, N. J. 1990. Mobilization of volatile toxic components from petroleum product-contaminated soils by TCLP, ASTM Spec. Tech. Publ., 1062 (Waste Test. Qual. Assur.: Second Volume): 228-243.

Roques, D. E.; Overton, E. B.; Henry, C. B. 1994. Using gas chromatography/mass spectroscopy fingerprint analysis to document process and progress of oil degradation, Journal of Environmental Quality 23(12): 851-855. doi:10.2134/jeq1994.00472425002300040034x

Saari, E.; Perämäki, P.; Jalonen, J. 2008. Measurement uncertainty in the determination of total petroleum hydrocarbons (TPH) in soil by GC-FID, Chemometrics and Intelligent Laboratory Systems 92(1): 3-12. doi:10.1016/j.chemolab.2007.11.006

Seo, J.-S.; Keum, Y.-S.; Li, Q.X. 2009. Bacterial degradation of aromatic compounds, International Journal of Environmental and Public Health 6(1): 278-309. doi:10.3390/ijerph6010278

Standard methods for the examination of water and wastewater, $19^{\text {th }}$ edition, 1995.

Taylor, C.; Viraraghavan, T. 1999. A bench-scale investigation of land treatment of soil contaminated with diesel fuel, Chemosphere 39(10): 1583-1593. doi:10.1016/S0045-6535(99)00056-9

US EPA Method 8015B.1986. Total petroleum hydrocarbons (TPH) analysis gasoline and diesel fuel.

US EPA Method 8020B. 1992. GC/MS Gas chromatographyMass spectrometry.

US EPA Method 9071A. 1994. Oil and grease-extraction for sludge and sediments. EPA Report SW-846, Chapter 5.

US EPA Method 1664. 2002. N-hexane extractable material (HEM) and silica gel treated n-hexane extractable material (SGT-HEM) by extraction and gravimetery (Oil and grease and total petroleum hydrocarbons).

Wang, Z.; Fingas, M. 1997. Developments in the analysis of petroleum hydrocarbons in oils, petroleum products and oil-spill-related environmental samples by gas chromatography, Journal of Chromatography A 774(1-2): 51-78. doi:10.1016/S0021-9673(97)00270-7

Wang, Z.; Li, K.; Fingas, M.; Sigouin, L.; Ménard, L. 2002. Characterization and source identification of hydrocarbons in water samples using multiple analytical techniques, Journal of Chromatography A 971(1-2): 173-184. doi:10.1016/S0021-9673(02)01003-8 


\title{
ALIEJU IR RIEBALŲ, BENDROJO NAFTOS ANGLIAVANDENILIU KIEKIO IR LAKIOSIOS ORGANINĖS FRAKCIJOS NUSTATYMAS DIRVOŽEMIO BEI DUMBLO PAVYZDŽIUOSE
}

\section{T. Rauckyte, S. Žak, Z. Pavlak, A. Oloyede}

\section{Santrauka}

Aprašomi nafta užterštų dirvožemio bei dumblo pavyzdžiai, kuriuose duju chromatografijos būdu GC-FID nustatytas bendrasis naftos angliavandenilių kiekis (TPH), o GC-MS - lakieji aromatiniai junginiai: benzenas, toluenas, etilbenzenas ir ksilenai (BTEX) bei naftalenas. Sonifikacijos n-heksane būdu nustatytas aliejų ir riebalu $(\mathrm{O} / \mathrm{G})$ kiekis. TPH ir O/G santykis rodo, kad angliavandenilių frakcijos yra nuo 7 \% iki $87 \%$. Lakioji organiné frakcija (BTEX) sudaro palyginti mažą bendrojo naftos angliavandenilių kiekio (TPH) dali, o BTEX ir TPH santykis svyruoja nuo 0,1 \% iki 0,6 \%. Ypač vertètų atkreipti dèmesi i bendrojo naftos angliavandenilių kiekio (TPH) nustatymą dujų chromatografijos būdu, nes galimas lakiosios organinès frakcijos (BTEX) pavojingumas gali būti nepakankamai įvertintas.

Reikšminiai žodžiai: dirvožemis ir dumblas, aliejai ir riebalai, bendrasis naftos angliavandenilių kiekis, lakieji aromatiniai junginiai.

\section{ОПРЕДЕЛЕНИЕ КОЛИЧЕСТВА МАСЕЛ, ЖИРОВ, СУММАРНЫХ НЕФТЯНЫХ УГЛЕВОДОРОДОВ И ЛЕТУЧИХ АРОМАТИЧЕСКИХ СОЕДИНЕНИЙ В ОБРАЗЦАХ ПОЧВЫ И СЕДИМЕНТА}

\author{
Т. Рауцките, С. Жак, З. Павляк, А. Олойеде
}

Резюме

Описаны образцы почвы и седимента, в которых способом хроматографии газа GC-FID определено общее количество нефтяных углеводородов (TPH), при помощи GC-MS установлены летучие ароматические соединения: бензол, толуол, этилобензол, ксилолы (BTEX) и нафталин. Способом сонификации в н-гексане определено количество масел и жиров (O/G). Отношение (TPH) / (O/G) свидетельствует о том, что в них содержится от 7\% до 87\% фракции углеводородов. Летучие ароматические соединения составляют относительно небольшую часть суммарных нефтяных углеводородов, а отношение (BTEX) / (ТРН) колеблется в пределах 0,1-0,6\%. Особое внимание следует обратить на определение общего количества нефтяных углеводородов (ТРН) способом хроматографии газа в связи с тем, что может быть не полностью оценена возможная опасность летучих ароматических соединений (BTEX).

Ключевые слова: почва/седимент, масла и жиры, суммарные нефтяные углеводороды, летучие ароматические соединения.

Teresa RAUCKYTE. Dr, Dept of Technology and Chemical Engineering, University of Technology and Life Sciences, Bydgoszcz, Poland. Her research expertise is heavy metal ions in used engine oils, sludges, soil and environmental pollution. She has published about 50 scientific papers in international journals and conferences proceedings, parts of monographs.

Sławomir ŻAK. Dr, Dept of Technology and Chemical Engineering, University of Technology and Life Sciences, Bydgoszcz, Poland. His research expertise is environmental technology and analysis of environmental pollution. He is a fellow of Polish Hydrology Society and Ecological Chemistry and Engineering Society. He has published about 75 scientific and technical papers in international journals and conferences proceedings, also is an author of parts of monographs and 18 patents.

Zenon PAWLAK. Prof., Dr Habil, University of Economics, Bydgoszcz, Poland. His research expertise is in lubrication of engine oils, lubrication of human joints, environmental pollution and radiochemistry. He is a fellow of American Chemical Society and Polish Chemical Society. He has published about 190 papers in international journals and conferences, edited a number of special issues of international journals and conference proceedings.

Adekunle OLOYEDE. Prof., Queensland University of Technology, Brisbane, Australia. He is an established and wordacknowledged expert in the area of connective tissue research and in particular articular cartilage biomechanics. He has published notable concepts contributing to fundamental thoughts in the field. His research has led to 7 patents, 30 scientific papers in international journals. Also is an author or co-author of numerous conferences papers and parts of monographs. 